\title{
H3-4 Gene
}

National Cancer Institute

\section{Source}

National Cancer Institute. H3-4 Gene. NCI Thesaurus. Code C154669.

This gene is involved in the packaging of DNA into nucleosomes. 